Please do not destroy or throw away this publication. If you have no further nae for it write to the Geological Survey at Washington and ask for a frank to return it

DEPaRTMENT OF THE INTERIOR

Hubert Work, Secretary

U. S. GEOLOGICAL BURVEY

George Otis Smith, Director

Water-Supply Paper 596-E

\title{
QUALITY OF THE SURFACE WATERS OF NEW JERSEY
}

\author{
BY \\ W. D. COLLINS AND C. S. HOWARD
}

Contributions to the hydrology of the United States, 1927

(Pagea 89-119)

Published September 30, 1927

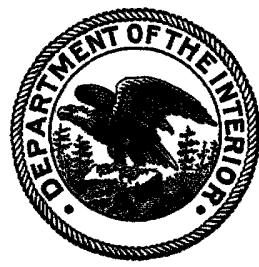

UNITED STATES

GOVERNMENT PRINTING OFHICF

WASHINGTON 


$$
\text { - }
$$




\section{CONTENTS}

Introduction___ $\quad \begin{array}{r}\text { Page } \\ 89\end{array}$

Natural features__._..._... 90

Surface features._._. 90

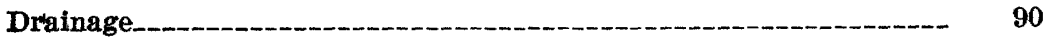

Climate - 91

Economic features._._. 92

Population - 92

Agriculture__._. 92

Mining - 92

Manufacturing_-_._- 92

Surface waters_____ 93

Samples_______._. 93

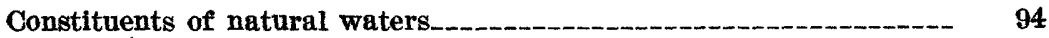

Methods of analysis_______ 95

Uses of water._-_. 96

Public supply___-__ 96

Power plants______. 96

Textile mills_____ 96

Treatment of water. 97

Temperature _. 98

Chemical character._._. 99

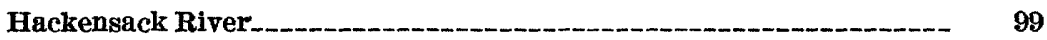

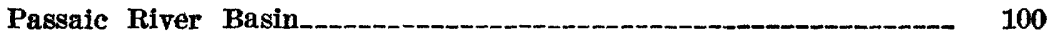

Passaic River-_._. 100

Tributaries of Passaic River._- 100

Rockaway River.___._. 100

Whippany River___. 101

Pompton River-_._. 102

Ramapo River -

Wanaque River._. 103

Pequannock River____ 104

Saddle River._._. 104

Summary _- 104

Elizabeth River____ 104

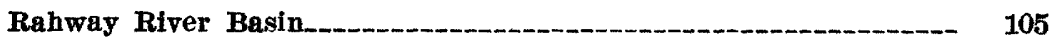

Rahway River_._. 105

Robinsons Branch

Raritan River Basin_______. 105

South Branch of Raritan River._._. 106

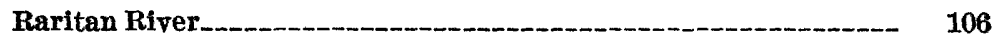

North Branch of Raritan River._._._. 106

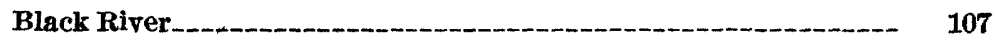

Millstone River

Stony Brook____ 107 
Surface waters-Continued.

Raritan River Basin-Continued. Page

Green Brook

Lawrence Brook

Summary_-_._. 108

Swimming River._- 108

Mullica River Basin_______._. 108

Mullica River._._._- 108

Batsto River____._. 109

Wading River

Absecon Creek _._. 109 ,

Great Egg River.___._. 109

Maurice River._-_____ 110

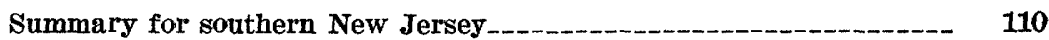

Delaware River Basin___._. 110

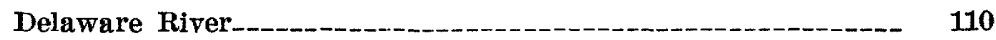

Tributaries of Delaware River. 111

Flat Brook

Paulins Kill:-__- 111

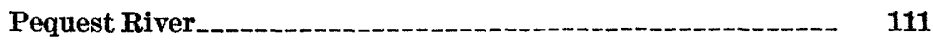

Beaver Brook

Musconetcong River._. 112

Assunpink Creek

Rancocas Creek

Coopers Creek

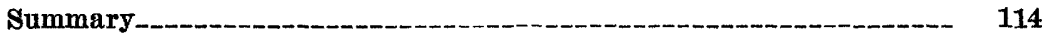

Analyses of surface waters_._. 114

\section{ILLUSTRATIONS}

Platw 10. Map showing location of sampling points for surface waters of New Jersey.

Frgure 16. Range in composition of samples of water from rivers in New Jersey.

17. Analyses of surface waters of New Jersey 


\title{
QUALITY OF THE SURFACE WATERS OF NEW JERSEY
}

\author{
By W. D. Coluins and C. S. Howard
}

\section{INTRODUCTION}

New Jersey is one of the leading industrial States. In volume of manufacturing the State is well up among the leaders, and its industrial activity to the square mile measured by the value added by manufacture as stated in the report on manufactures of the Fourteenth Census is greater than that of any other State except Massachusetts and Rhode Island. In the industrial development of the State the excellent quality of its surface waters has played no small part. Formerly the quantity of water was ample, but in recent years manufacturing has been halted for brief periods on account of shortage of water.

The New Jersey Department of Conservation and Development, in cooperation with the United States Geological Survey, has been making extensive studies of the quantity of ground and surface water available in certain parts of the State. In connection with the measurements that have been made of the discharge of the larger streams samples of water have been collected from time to time for chemical analysis. (See pl. 10.) The analyses given in the table on pages 116-119 show the chemical character of the surface waters of the State and indicate their suitability for different kinds of industrial use.

The material relating to surface features and drainage that is presented herein is abstracted in the main from the following roports:

Lewis, J. V., and Kïmmel, H. B., The geology of New Jersey ; a summary to accompany the geologic map (1910-1912) on the scale of $1: 250,000$, or approximately 4 miles to 1 inch: New Jersey Geol. Survey Bull. 14, 1915.

Salisbury, R. D., The physical geography of New Jersey: New Jersey State Geologist Final Rept., vol. 4, 1898.

Vermeule; C. C., Report on water supply, water power, the flow of streams, and attendant phenomena: New Jersey State Geologist Final Rept., vol. 3, 1894.

Hazen, Whipple \& Fuller, Report on water resources of the State and their development, made to the Department of Conservation and Development, State of New Jersey, 1922.

The discussion of economic features is based on reports of the United States Census Bureau. Data in regard to climate are taken 
from publications of the United States Weather Bureau. Most of the figures for density of population in the drainage basins are from the report of Hazen, Whipple \& Fuller named above. The material relating to geographic features of the individual drainage basins is taken from the report of Vermeule, water-supply papers of the United States Geological Survey, and reports of the Corps of Engineers, United States Army.

\section{NATURAL FEATURES}

Surface features.-New Jersey, which is a part of the Atlantic slope, has an area of 8,224 square miles, 710 square miles of which is covered with water in bays, harbors, lakes, etc. Two major physiographic divisions are recognized in the Atlantic slope-the Appalachian Highlands and the Atlantic Plain. The boundary between these divisions in New Jersey is a line running through Trenton and New Brunswick.

The Appalachian Highlands in New Jersey include parts of three provinces-the Appalachian Valley, the New England province, and the Piedmont province. The Appalachian Valley is a belt of valleys and ridges crossing the extreme northwest corner of the State. This region includes about one-twelfth of the area of the State and is occupied by the upper valley of Delaware River and the Kittatinny Valley. The part of the New England province lying in New Jersey occupies a highland belt of strong relief 10 to 25 miles wide, which covers about one-eighth the area of the State. The maximum altitude is about 1,400 feet and the average about 1,000 feet. The Piedmont province in New Jersey is an extension of the plateau of the Southern States but is lower and more nearly a plain here than it is farther south. It is a region of rolling lowland with scattered ridges and hills. The altitude ranges from a few feet above sea level in the vicinity of Newark to 200 feet in the valleys of Passaic and Raritan Rivers, 300 feet north of Paterson and Hackensack, and 913 feet in the Hunterdon Plateau.

The Coastal Plain of New Jersey contains about three-fifths of the area of the State. It is a region of low relief, one-third of it having an altitude of less than 50 feet. About 4 per cent of the plain is tidal marsh. A few areas rise higher than 200 feet, but most of them are isolated hills.

Drainage.-The drainage of the western part of the State goes chiefly to Delaware River, but a few streams in the northwestern part, notably Wallkill River, are tributary to Hudson River. The northeastern and central parts of the New England province are drained by tributaries of Passaic and Raritan Rivers, which empty into Newark and Raritan Bays. The southwestern part of the State 
is drained by tributaries to Delaware River and Delaware Bay, and the southeastern part by streams flowing to the ocean. The divide separating the Delaware River drainage basin from the drainage to the ocean is in general about 15 miles east of the river, but Rancocas Creek has its headwaters about 30 miles from the river. More detailed descriptions of the individual drainage systems of the State are given on pages $99-114$.

Climate.-The following description of the climate of New Jersey is based on reports by G. Harold Noyes, meteorologist at the United States Weather Bureau station at Trenton, N. J., published as sections 99 and 100 of a summary of climatologic data for the United States by sections, covering the periods from the establishment of the several stations through the year 1920. For consideration of the climate the State is divided into northern and southern parts. The northern part is described in two natural divisions-the highlands and Kittatinny Valley district, comprising about 1,650 square miles, and the red sandstone plain (Piedmont province), comprising about 1,500 square miles. The area of the southern part is about 4,400 square miles.

The. annual rainfall in New Jersey is generally uniform throughout the State, but there are seasonal and daily variations between different sections. The heavier local showers occur on the shore in summer. In the highlands and Kittatinny Valley the storms are less severe and longer.

The normal annual precipitation for the State, based on observations for about 40 years, is 46.54 inches and has ranged from a minimum of 37.29 inches in 1895 to a maximum of 63.33 inches in 1889. The precipitation has been below the average each year since 1920, when it was 51.87 inches. In 1923 it .was 40.38 inches; in $1924,44.17$ inches. It is probable, therefore, that the river discharges have been slightly below normal in the period during which analyses were made for this report.

The temperature of the northern part of the State has a normal range from $100^{\circ}$ above to $20^{\circ}$ below zero, and that of the southern part from $100^{\circ}$ to zero. The higher altitude of the northern part of the State accounts for the lower temperature. In the southern part along the shores, owing to the modifying influence of the Atlantic Ocean and Delaware Bay, the ranges of daily, monthly, and annual temperatures are much less than in the interior, although the mean temperatures are much the same. The mean monthly temperatiures for the State for July and August are 73.2 and 71.9; from December to February the mean monthly. temperature is near the freezing point. 


\section{FCONOMIC FEATURES}

Population.-New Jersey is one of the most densely populated States, having 420 inhabitants to the square mile at the time of the Fourteenth Census in 1920. Only Massachusetts and Rhode Island were more densely populated. The northern part of the State has more population than the southern part. Mercer and Monmouth Counties and those north of them have 51 per cent of the land area of the State and 83 per cent of the population.

The rate of increase of population of the State has been greater than the average rate for the United States since 1860. The increase from 1910 to 1920 was 24.4 per cent for New Jersey and 14.9 per cent for the whole United States. The increase for the northern half of the State was 24.6 per cent and for the southern half 23.2 per cent. This increase of population has made it imperative to study the conservation of both surface and ground waters for use as public supplies as well as for manufacturing.

Agriculture.-New Jersey is not one of the leading agricultural States, but the gross value of all agricultural products per square mile of land area in 1919 was exceeded in only four other States. Thus it appears that agriculture is not an unimportant economic factor in the State. The total gross value of agricultural products in 1919, however, it was only about one twenty-seventh the value of the products manufactured in the State in the same year. The percentage of the land area of the State reported as farm land decreased from 53.5 in 1910 to 47.5 in 1920.

Mining.-Although the value of the products of the mining industry in New Jersey in 1919 was only 0.3 per cent of the total for the United States, the State ranked high in the production of zinc ore and was second in the quarrying of basalt or trap rock and in the mining of clay. The greensands of New Jersey are finding a rapidly increasing use in water treatment. ' After suitable preparation the sands have valuable properties of base exchange, rapid regeneration, and long life. The mining and quarrying industries make no unusual demands on the water resources and do not affect the quality of water in the streams to any great extent.

Manufacturing.-New Jersey is primarily a manufacturing State. At the time of the Fourteenth Census it ranked sixth among the States in the value of manufactured products. This value was more than twenty-seven times the gross value of all farm products of the State and nearly four hundred times the value of the products of its mines and quarries.

As a measure of industrial activity the figures given in census reports as "value added by manufacture" are more useful than those given for "value of products." The latter may include the 
value of a given raw material several times as the product of one manufacturing process is passed along to serve as material for another. The value added by manufacture is the difference between the value of the finished products and the cost of materials and thus involves no duplication. The further discussion of industrial activity in this report is based on the value added by manufacture for the different commodities considered. ${ }^{1}$

In 1919 New Jersey ranked second among the States in the production of chemicals, the dyeing and finishing of textiles, petroleum refining, and silk manufactures. It was third in the production of rubber goods and fourth in canning and preserving, the production of jewelry, and the production of leather, tanned, curried, and finished. In silk products the value added by manufacture in New Jersey was 30.6 per cent of the total for the United States, and in the dyeing and finishing of textiles 23.5 per cent of the total. The leading industries of the State in 1919 were shipbuilding; steel; silk goods; foundry and machine-shop products; electrical apparatus, machinery, and supplies; petroleum refining; worsted goods; iron and steel works and rolling mills; rubber tires, tubes, and rubber goods not elsewhere specified; and dyeing and finishing textiles, exclusive of that done in textile mills. As reported in the Fourteenth Census, the 10 industries just named represented 41.6 per cent of the total industrial activity of the State.

Several of the imdustries named above are not dependent on the quality of water except as it is used in boilers for the generation of steam. Other industries, particularly the manufacture and dyeing of textiles, are greatly affected by the chemical character of the waters available. The study of industrial development cited above showed that these industries have largely remained in regions where soft waters are found, and that other industries have grown up in places where the natural waters are generally hard. The industrial plants of the State have seriously polluted some of the streams. Most of the polluting material is organic matter, and its presence is not shown by the analyses given in this report.

\section{SURFACE WATERS}

\section{SAMPLES}

The chemical composition of a surface water usually changes with variations in the discharge. In most streams the water shows the greatest concentration of dissolved material at low stages and the least at high stages. Sometimes, however, a stream fed by tributaries draining areas of different geologic character may have an

${ }^{1}$ See Collins, W. D., Relations between quality of water and industrial development in the United States: U. S. Geol. Survey Water-Supply Paper 559, 1926.

$52250^{\circ}-27-2$ 
increase in dissolved solids in time of a flood coming from an area that supplies much larger quantities of soluble salts than are supplied by the average soil of the whole drainage basin. The mineral matter dissolved in a given quantity of water taken from a river at low water may easily be twice as great as that in the same quantity taken at high water. Therefore a single sample from a river may give a decidedly misleading impression of the content of dissolved material generally to be found in the water.

The most reliable way to learn the chemical character of water to be obtained from a stream is to make analyses of composites of daily samples taken over a period of at least a year. The composites may represent long or short periods. If the periods are too long, the variations in composition are smoothed out too much; on the other hand, the cost of analyses makes it desirable to keep the number as small as possible. In general, composites of either 7 or 10 daily samples give the most information for the amount of money spent for the analyses. If the composition of a water does not change rapidly, a 30-day composite may be satisfactory.

The river waters of New Jersey do not change in composition so much as many other surface waters in the United States. During the time covered by the collection of the samples for which analyses are given in this report the discharge of most of the rivers was known for each day. It is possible, therefore, to use a few analyses representing different stages of the streams to show the probable character of the water at any other stage. Single samples have been collected at all the gaging stations maintained by the State Department of Conservation and Development in cooperation with the United States Geological Survey. (See pl. 10.) The collections made at most stations cover the usual range of discharge. In addition several samples have been taken from streams on which there are no gaging stations. The samples were all collected by or under the direction of $O$. W. Hartwell, district engineer of the Geological Survey, in charge of the stream gaging in New Jersey.

\section{CONSTITUENTS OF NATURAL WATERS}

The surface waters of New Jersey are fairly clear, but they generally carry small quantities of suspended matter. Most of this is finely divided rock material. The waters in the northern part of the State are usually not highly colored, except as they may be polluted with wastes that contain coloring material. Some so-called "natural" color is obtained from decaying leaves and other organic matter. In the southern part of the State the waters are highly colored.

The surface waters carry also mineral matter in solution, which is dissolved from the rocks and soils. The greater part of the 


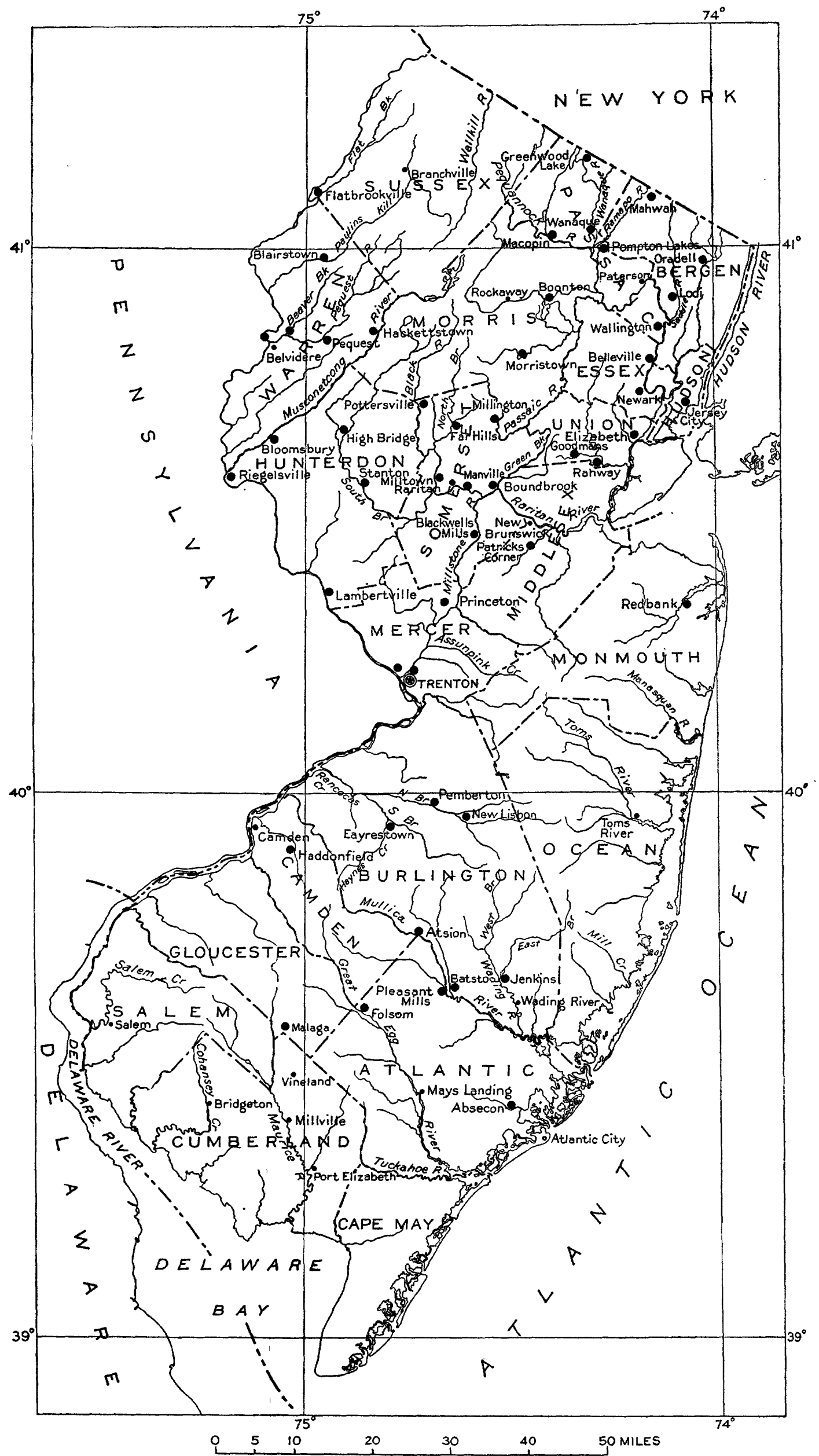



dissolved material in most waters consists of bicarbonates of calcium and magnesium, which are obtained most easily by the solution of limestone and dolomite but are also taken up from other rocks. Sodium and potassium are present in comparatively small quantities in most of the waters. Sulphate, chloride, and nitrate are also usually minor constituents. Silica and iron are present in normal amounts in most of the New Jersey waters. The silica may make up from 10 to 30 per cent of the total mineral matter; the quantity of iron is generally much less than 1 part per million. Iron dissolved in stream waters that are not acid is quickly oxidized by the air and precipitated. This freshly precipitated iron oxide or hydroxide is as harmful as dissolved iron in some uses of the water. The iron in the suspended material of the waters is therefore reported for a good many of the analyses.

\section{METHODS OF ANALYSIS}

The samples collected for this report were analyzed by methods that involve only minor departures from the standard methods of the American Public Health Association. The results given in the table are reported in parts per million.

Many of the samples were clear when collected and when analyzed. Others carried appreciable amounts of suspended matter, and these were filtered through asbestos in a Gooch crucible, and the weight of the suspended matter was determined after drying at $180^{\circ} \mathrm{C}$. The filtered sample was used for analysis of the dissolved mineral matter. Some samples that were clear when collected contained precipitated iron at the time of analysis. The quantity of iron precipitated was determined and added to the quantity found in solution to give the result reported under the heading "Total iron." Some of the iron so reported may have been in solution when the samples were collected, but some undoubtedly came from the material suspended in the samples at the time of collection.

A convenient quantity of the water, usually 1 liter, was evaporated to dryness in platinum; the residue was heated to constant weight at $180^{\circ} \mathrm{C}$. and weighed to determine the total dissolved solids. Silica was separated by evaporation with hydrochloric acid and after ignition was volatilized with hydrofluoric acid. Sulphate was determined as barium sulphate in the filtrate from the silica. Sodium and potassium in the filtrate from the barium sulphate were purified and weighed as mixed chlorides. In most of the analyses this weight was calculated to the equivalent sodium. In a few analyses potassium was determined by weighing the reduced platinum from potassium platinic chloride. In most of the analyses a second portion, usually. 1 liter, was slightly acidified and then concentrated in a 
resistant glass beaker, and the iron was precipitated as hydroxide and determined colorimetrically. In the filtrate from the iron the calcium was determined by titrating the oxalate with permanganate; magnesium was weighed as the pyrophosphate. Chloride, carbonate, and bicarbonate were determined by the usual titrations, and nitrate by the phenoldisulphonic acid method. The calculated hardness is reported as the calcium carbonate equivalent to the calcium and magnesium together.

\section{USES OF WATER}

Pubtionsupply.-The most important use of water is to furnish a public supply, and the essential requirement for such use is that the water be safe to drink. This quality does not depend on the mineral content in New Jersey-in fact, there are few places where it does. The studies made for this report take no account of pollution that may make water unfit for drinking, but the processes employed to purify polluted water may affect its composition to the advantage or disadvantage of the industrial user. Although the water used for drinking sets the standard of purity for the whole of a public supply, the quantity so used is relatively small-generally between 0.5 and 1 per cent of the total. A large proportion of the water of public supplies in New Jersey is used by industrial establishments for the generation of steam in power plants and for various manufacturing processes.

The purification of a surface water to make it safe to drink generally involves treatment that also removes turbidity and color. Hence a surface water treated for a public supply may be much more desirable for industrial use than untreated water from the same source. Unless the plant requires very large quantities of water, it is usually cheaper to buy treated water from a public waterworks system than to undertake purification for one plant.

Power plants.-The most common industrial use of water is in boilers used to generate steam for power or heating. The surface waters of New Jersey are among the best in the United States for boiler use. Most of them can be used with little treatment. In steam plants using large quantities of "make-up water" and operating above their rated capacity it is found profitable to treat the waters. Constituents that are undesirable in a feed water are acidity, high chloride or sulphate with much calcium and magnesium, calcium and magnesium, and suspended matter. At many plants large quantities of cooling water are used, principally for the condensers of steam turbines or other engines. A low temperature is, of course, the most essential characteristic for this cooling water.

Textile mills.-Silk, wool, and cotton manufacturing plants generally require large quantities of pure water. For the best results in 
most of the processes in which water is used it should be free from color, suspended matter, calcium and magnesium (hardness), iron, and any unasual constituents such as acids or free caustic alkali, which are rarely found in natural waters but are present in some waters that are polluted or have been treated chemically. Some of the New Jersey surface waters can be used in the textile industries without treatment, but many plants in New Jersey find it necessary or profitable to treat the water for the removal of color, suspended matter, iron, and hardness.

\section{TREATMENT OF WATER}

The treatment of water is discussed briefly in two previous publications of the Geological Survey ${ }^{2}$ and is described in detail in several well-known texts. ${ }^{3}$ In connection with discussions of the quality of surface waters of New Jersey it will suffice to mention several processes of treatment that relate to the chemical character of the waters.

Surface waters are generally filtered for public supplies. As the possibilities for pollution increase and higher standards with respect to color and turbidity are demanded the exceptions to this practice will become much fewer. The common procedure in filtration includes coagulation with an aluminum or iron salt, followed by sedimentation and rapid filtration through sand. Most of the surface waters of New Jersey have so little alkalinity that either lime or soda ash or both must be added to obtain proper coagulation with the aluminum salt.

In some parts of the country natural waters are softened for public supplies. The softening generally leaves a residual hardness of about 100 parts per million. The limit of the softening regularly accomplished by a lime-soda softener operating in the cold is close to 50 parts per million of hardness. Most of the surface waters in New Jersey have less hardness, and therefore the lime-soda process, which is extensively used in places where the natural waters are very hard, is not generally applicable to the New Jersey surface waters.

The exchange-silicate process, which softens water almost completely by an exchange of sodium for the calcium and magnesium, finds a particularly inviting field where the natural waters are comparatively soft. The softened water does not have the large quantity

${ }^{2}$ Collins, W. D., The industrial ntility of public water supplies in the United States: U. B. Geol. Survey Water-Supply Papex 496, pp. 18-27, 1923 ; Relations between quality of water and industrial development in the United States: U. $\mathbf{8}$. Geol. Snrvey Water Supply Paper 559, pp. 22-27, 1926.

3 EHlms, J. W., Water purifleation, MeGraw-Hill Co., 1917, Mason, W. P..; Water supply, John Wiley \& Sons, 1916. Stein, M. F., Water-purification plants and their operation, John Wiley \& Sons, 1920. Turneaure, F. E., and Eussell, H. L., Public water supplies, John Wiley \& Sons, 1924. 
of sodium salts that will be found in a very hard water softened by an exchange silicate; the costs of installation and of operation of an exchange-silicate softener to deliver a given number of gallons of softened water per day are much less for the soft water than for the hard water.

Some waters require treatment to render them noncorrosive. . The surface waters of New Jersey are practically free from unneutralized acid, such as is found in streams that drain coal fields. They are therefore not intensely corrosive like the waters that destroy iron and steel structures exposed to their action. It is the general experience, however, that soft waters like those of New Jersey are much more active than very hard waters in the relatively mild attack on the interior of iron or steel pipes used in streets and buildings. At many purification plants, where soft. waters are treated, it is necessary to take special precautions to avoid making the filtered water more corrosive than the water before filtration.

\section{TEMPERATURE}

Where water is used for cooling, as at an ice plant or for condensers, its initial temperature governs the economy of the operation. The higher the temperature the more water must be pumped for a given amount of cooling, and in summer the temperature of a surface water may be so high that the plant must be run at low efficiency, even with greatly increased pumpage.

A recent publication of the Geological Survey ${ }^{4}$ supplies a basis for estimating the probable temperature of surface waters throughout the United States. Charts of water temperatures and the figures for air temperatures obtained from reports of the United States Weather Bureau indicate that the temperature of surface water in New Jersey during the months of July and August is not far from $75^{\circ} \mathrm{F}$. This is much warmer than the ground water at depths of 60 to 100 feet, where the temperature is from $52^{\circ}$ to $57^{\circ} \mathrm{F}$. the year around. From June to September surface waters in New Jersey are decidedly warmer than ground water from the depths mentioned, from November to April they are colder, and in May and October there is usually little difference.

Several writers have pointed out that where lakes or reservoirs are deep enough cool water can be obtained in summer by drawing it from depths of more than 20 or 25 feet below the surface. This water may be cooler than the ground water that has the mean annual air temperature.

- Collins, W. D., Temperature of water available for industrial use in the United states:

U. S. Geol. Survey Water-Supply Paper 520, pp. 97-104, 1924. 


\section{CHEMICAL CHARACTER}

The chemical character of the surface waters of New Jersey is shown by the analyses in the table. Typical analyses for some drainage basins are shown graphically in Figures 16 and 17.

In general, the waters are fairly clear, not highly colored, and of low mineral content. The predominating constituents are calcium, magnesium, and bicarbonate. Sodium, chloride, and sulphate occur in relatively small quantities in nearly all the unpolluted waters. Sewage pollution increases the sodium chloride; industrial wastes may increase the sulphate also.

The range in concentration shown in Figure 16 for Passaic River and for North Branch of Raritan River is about the same as for Delaware River, although the samples for the first two were selected single samples, and the analyses for Delaware River were made on a series of composites of daily samples covering a period of a year.

In the following pages the characteristics of the surface waters of the State are taken up by drainage basins. Streams for which no analyses are available yield water of about the same composition as is found in other streams that drain areas of similar geologic character.

\section{HACKENSACK RIVER}

Hackensack River rises near Haverstraw, N. Y., and empties into Newark Bay. Its drainage area is about 202 square miles, of which 64 square miles is in New York. The watershed on the east along its whole course extends within half a mile of the west bank of the Hudson. The drainage basin above New Milford has an area of 115 square miles and is covered with glacial drift, sand, and gravel. The river is navigable and tidal to New Milford, and a large part of the basin below New Milford is tidal meadow. Pascack Creek, with a drainage area of 28 square miles, is the largest tributary to the Hackensack.

The population of the basin is about 325 per square mile. The principal large places are Hackensack and Rutherford, which in 1920 had populations of 17,627 and 9,497, respectively.

The Hackensack Water Cọ. has a storage reservoir at Oradell, 1 mile north of New Milford, which supplies water to several municipalities of northeastern New Jersey. The total population' supplied in 1920 was about 256,000 . The flow of the river is so nearly all used for these supplies that for several days in the summer no water goes over the dam at New Milford. The maximum discharge for the year ending September 30, 1924, was 1,800 second-feet.

Analysis 1 shows the composition of a sample collected at the Oradell reservoir. The filtered water used for the public supplies 
is free from suspended matter and low in color. It contains slightly more sulphate and less bicarbonate than the unfiltered water represented by the analysis.

Analyses made at the filtration works by G. R. Spalding indicate that the sample analyzed for this report had slightly more dissolved mineral matter than the average over a period of several years. Its hardness and total dissolved solids are less than the maximum and considerably greater than the minimum found by Mr. Spalding.

\section{PASSAIC RIVER BASIN}

PASGAIC RIVER

Passaic River rises in Morris County a short distance from the headwaters of the North Branch of Raritan River and flows into Newark Bay. The distance by direct line from the source of the Passaic to its mouth is not more than 25 miles, but its course is very rambling and is about 80 miles long. The river heads in the highlands, but most of its drainage area is in the Piedmont province, where the principal tributaries, except Saddle River, join the main river. The area of the whole drainage basin is about 949 square miles; the part above Millington covers 55 square miles, and its population is 102 to the square mile. The maximum and minimum discharges at Millington for the year ending September 30, 1924, were 1,100 and 2.5 second-feet.

Analyses of five samples from Passaic River at Millington (Nos. 2-6) show that the water is soft and low in mineral content. A sample collected in October, 1924, was highly colored. The turbidity was determined on two of the samples and was not very high, although one of these samples (No. 2) was taken at a high stage (discharge 980 second-feet). Analyses 2 and 6 are shown graphically in Figure 16 to illustrate the change in concentration of the river water with a changing rate of discharge. Analysis 6 is shown in Figure 17 also, for comparison with analyses of other waters from the Passaic Basin.

Analyses of two other samples of the water of Passaic River, one collected at Wallington (No. 7) and one at Belleville (No. 8), show that the water is more concentrated at these points, which are nearer the mouth of the river, than at Millington.

\section{TRIBUT'TARIES OF PABSAIC RIVHB}

Rockowiay River.-Rockaway River rises and has most of its drainage area of 140 square miles in the highlands. The river is 40 miles long and flows into the Passaic about 2 miles below Beaufort. The drainage area above Boonton covers 119 square miles and has a 
population of 210 to the square mile. A dam on the river at Boonton stores water for the supply of Jersey City. The mean discharge including diversion and allowing for storage for the year ending September 30, 1924, was 223 second-feet.

An analysis of a sample collected for this report in November, 1923, at the intake of the Jersey City waterworks (No. 10) shows hardness about the same as the average hardness that was reported by the city waterworks for 1923 , but the water was a little more concentrated than the sample represented by an analysis made in 1922 (No. 9). Analysis 10 is shown graphically in Figure 17.

Whippany River.-Whippany River rises in the highlands and enters Rockaway River just above the junction of the Rockaway and the Passaic. The Whippany has a drainage area of 71 square miles,

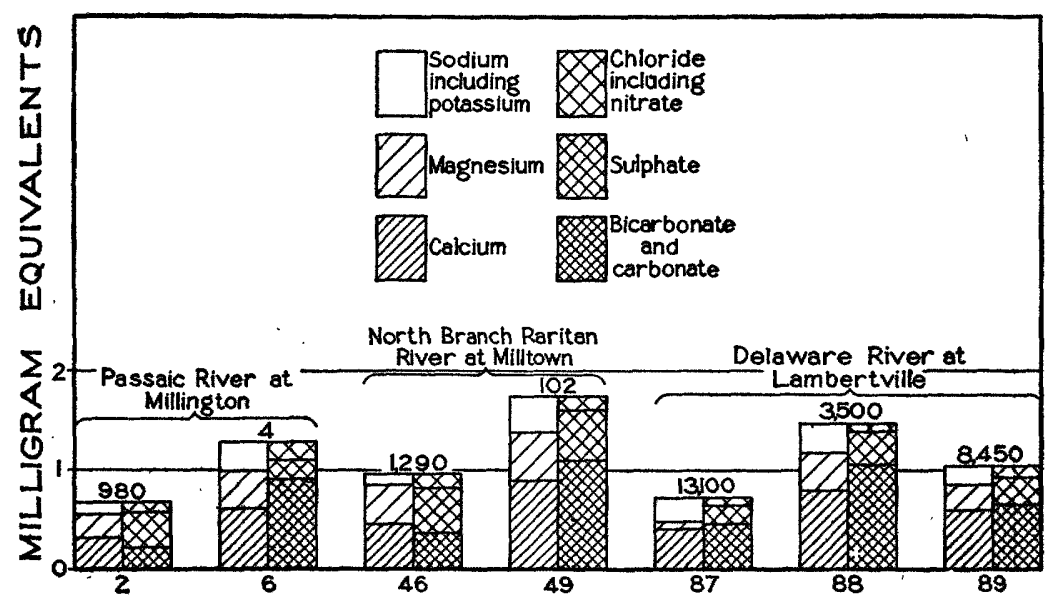

Frevan 16.-Range in composition of samples of water from rivers in New Jersey. Numbers below diagrams refer to analyses in table on pages 116-119. Figures above diagrams indicate discharge in second-feet.

of which 46 square miles is in the Piedmont province. The drainage area, including Morristown, the largest incorporated place in the basin, is 29 square miles, and the maximum and minimum discharges below Morristown for the year ending September 30, 1924, were 830 and 8 second-feet. Effluent from the sewage plant of Morristown flows into the river below the town and below the gaging station where samples of the river water were collected.

Analyses of three samples collected at Morristown (Nos. 11-13), representing water from the highlands drainage area, show that the water is slightly hard but low in total mineral content. There is no great change in composition within the range of discharge covered by the three samples. Analysis 13 is shown graphically in Figure 17. 


\section{CONTRIBUTIONS TO HYDROLOGY OF UNITED STATHS, 1827}

Pompton River.-Pompton River, formed by the junation of Ramapo and Pequannock Rivers, flows through the Piedmont province into the Passaic. The composition of jts water is within the

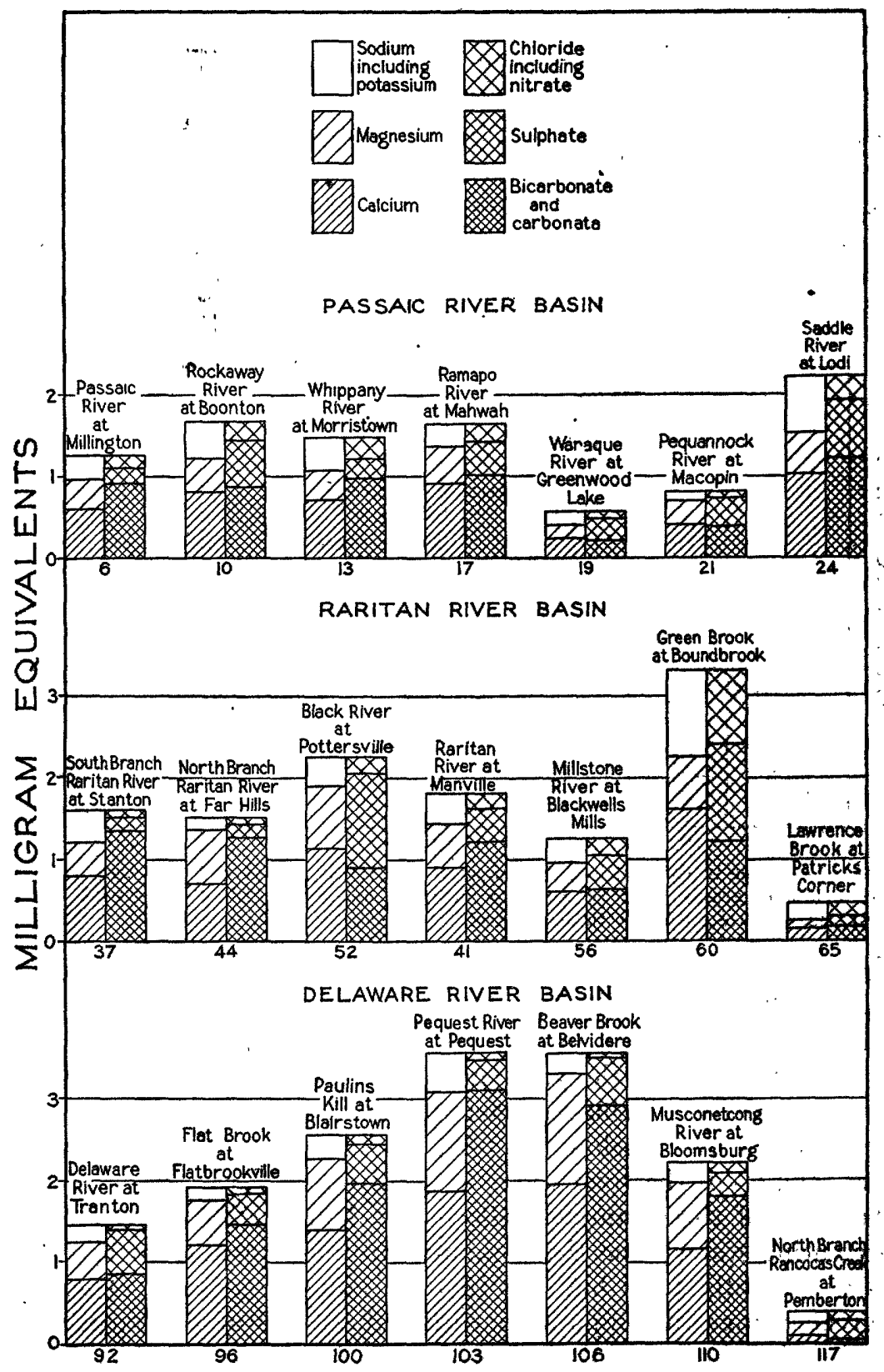

Fradral 17.-Analyses of surface waters of New Jersey. Numbers below diagrams reter to analyses in table on pages 116-119 
range of composition of the Ramapo, Wanaque, and Pequannock, as shown by analyses 14 to 21 .

Ramapo:River.-Ramapo River rises in New York, and about 70 per cent of its total drainage area of 160 square miles is in that State. In New Jersey the river may be considered a highland stream. A dam at Pompton stores water for generating power, and below Pompton the Ramapo joins the Pequannock and Wanaque to form Pompton River. At the gaging station near Mahwah the maximum and minimum discharges for the year ending September 30,1925 , were 2,400 and 15 second-feet.

Four samples taken from Ramapo River near Mahwah (Nos.14-17) show that the water is low in mineral content and slightly hard. One sample from the river at Pompton Lakes (No. 18) had a similar composition. Analysis 17 is shown graphically in Figure 17.

Wanaque River.-Wanaque River has its source in Greenwood Lake, at an altitude of 621 feet. The lake has a surface of 3 square miles and receives drainage from an area of 27 square miles, part of which is in New York. The river flows 18 miles and empties into Pequannock River, at Pompton. Most of its drainage area is in the highlands.

Wanaque River above Wanaque has a drainage area of 91 square miles; the population in this area is about 25 to the square mile. In the year ending September 30, 1924, the maximum discharge at Wanaque was 5,050 second-feet and the minimum 1.4 second-feet. This river is now being developed as a source of water supply by the North Jersey District Water Supply Commission. A report of the commission for the period May 5, 1916, to June 30, 1925, gives a full account of the development, with reports by the consulting engineers, Weston \& Sampson, on the bacterial and chemical character of surface waters in the district. The chemical analyses are not complete analyses of the mineral content but give the results of the determinations usually made in a sanitary chemical analysis.

Analyses 19 and 20 represent samples from Wanaque River, taken at Greenwood Lake and at Wanaque at comparatively low stages. Analysis 19 is shown graphically in Figure 17. Both of these analyses represent waters that would be classed as soft and of low mineral content. It is probable that the water to be stored in the reservoir is represented much better by No. 19 than by No. 20. Results abtained by the North Jersey District Water Supply Commission indicate that No. 20 shows an extremely high concentration, which is not likely to be reached when the reservoir is filled and water of average composition is let down to maintain the low-water flow. 
Pequannock River:-Pequannock River rises in the highlands, at an altitude of nearly 1,500 feet. It flows in a general southeasterly direction for 31 miles to its junction with the Ramapo at Pompton, where the altitude is 170 feet. The water is impounded at Macopin for the public supply of Newark. The drainage area above Macopin is 64 square miles.

Analysis 21, which is shown graphically in Figure 17, represents a sample collected in November, 1923. This analysis agrees well with results obtained over a period of several years by Justus Goslau for the city of Newark and sent to the United States Geological Survey by John A. Foulks, chief engineer of the division of water of that city. The analyses made by Mr. Goslau show generally a somewhat lower mineral content, although some samples had slightly greater concentration.

Saddle River.-Saddle River rises in New York and flows into Passaic River about 12 miles from Newark Bay. Of its drainage area of 61 square miles, 52 square miles is in New Jersey. Above Lodi the drainage area is 55 square miles. The maximum and minimum discharges for the year ending September 30, 1924, were 1,280 and 5.3 second-feet.

Analyses 22-24 represent different stages of the river at Lodi. Analysis 24 is shown graphically in Figure 17. The water of Saddle River is appreciably harder than most of the other waters tributary to the Passaic. The samples collected in November, 1923 (No. 24), and November, 1925 (No. 23), are much more concentrated than the sample collected during high water in February, 1924.

\section{SUMMARY}

The analyses for the Passaic Basin shown in Figure 17 are those of the most concentrated samples collected at the different points. They may not represent the highest concentrations reached over a long period, but most of them can be taken as showing approximately the greatest concentration likely to persist for any considerable time. Study of the analyses in the table, with consideration of the discharge corresponding to the analyses and those reported throughout the year, indicates that in general the waters are not greatly diluted for any long period. The concentration is not likely ever to be much less than half the maximum and is generally well over half the maximum.

\section{FLIZABETH RIVER}

Elizabeth River rises in the city of East Orange and flows into Newark Bay through Arthur Kill. Above Elizabeth, at the head of tidewater, it has a drainage area of 20 square miles, most of 
which is covered thickly with glacial drift. The maximum and minimum discharges of the river at a point below the intake of the Elizabethtown Water Co. for the year ending September 30, 1924, were 890 second-feet and zero. The drainage area has a large population and considerable manufacturing.

Analysis 25 represents a* sample collected above the reservoir of the water company, while rain was falling and the water was much more turbid than usual and probably less concentrated than the water generally held in the reservoir. Analyșes 26 and 27 represent samples collected at the gaging station below the reservoir, $21 / 2$ miles above the mouth of the river.

The analyses show that the water is hard and moderately high in mineral content. Its hardness is several times that of most of the other river waters in the northeastern part of New Jersey. The water also contains much more sodium and chloride than the other river waters of the State.

\section{RAHWAY RIVER BASIN}

Rahwowy River.-Rahway River is a small stream rising in a valley in the Watchung Mountains, west of Orange. The river flows south across the plain of glacial drift and empties into Arthur Kill a short distance from Newark Bay. The drainage area above Rahway, at the head of tidewater, is 41 square miles, most of which is covered with glacial drift. The river basin is densely populated and has considerable manufacturing. The maximum and minimum discharges at Rahway for the year ending September 30, 1924, were 1,100 and 2 second-feet. Ground water is withdrawn above Rahway by wells of the Orange Water Co. and the Short Hills Water Co., and water is also taken directly from the river by the Rahway Water Co.

Analyses of two samples taken from the river at Rahway (Nos. 28 and 29) indicate that the river water changes considerably in hardness and in mineral content with changing discharge.

Robinsons Branch.-The drainage area of Robinsons Branch of Rahway River above Goodmans is 12.7 square miles, and the maximum and minimum discharges at that point in the year ending September 30, 1924, were about 130 and 2 second-feet. The analysis of a sample collected in August, 1923 (No. 30), shows the water to be less concentrated than the water of the main stream at the same stage.

\section{RARITAN RIVER BASIN}

The Raritan River system is the largest in New Jersey, except the Delaware, but it is not economically as important as the Passaic, 
because the tributaries do not combine until they reach points within about 7 miles of tidewater. The whole Raritan drainage area is 1,105 square miles. The river is tidal to a point about 2 miles above New Brunswick and is navigable to that city.

South Branch of Raritan River.-The South Branch of Raritan River rises in Budd Lake, southwest of Lake Hopatcong. It is 42 miles long and drains 277 square miles. About 100 square miles of its drainage area is in the highlands, and the remainder is in the Piedmont province. At High Bridge the South Branch has a drainage area of 65 square miles. The maximum and minimum discharges at this point in the year ending September 30, 1924, were 2,500 and 19 second-feet. At Stanton the South Branch has a drainage area of 147 square miles, and the maximum and minimum discharges there for the year ending September 30, 1924, were 5,200 and 26 secondfeet.

Analyses of three samples collected at High Bridge (Nos. 31-33) and of four samples collected at Stanton (Nos. 34-37) show that the river water is slightly hard but is low in mineral content. Analysis 37 is shown graphically in Figure 17.

Raritan River.--Raritan River is formed by the union of the North Branch and South Branch near Raritan. At Manville the drainage area is 490 square miles; the maximum and minimum discharges at this point for the year ending September 30, 1924, were 20,000 and 38 second-feet. Analyses 38 to 41 , which represent samples collected at Manville, show the water to be slightly hard and of low mineral content. Analysis 41 is shown graphically in Figure 17.

North Branch of Raritan River.-The North Branch of Raritan River rises west of Morristown and unites with the South Branch near Raritan. It has a drainage area of 192 square miles, practically all of which is in the Piedmont province. At Far Hills this branch has a drainage area of 26 square miles and the maximum and minimum discharges for the year ending September 30, 1924, were 652 and 6 second-feet.

Analyses of samples taken at Far Hills (Nos. 42-45) indicate that in general the water is soft and of low mineral content. Analysis 44 is shown graphically in Figure 17.

At Milltown the drainage area of the North Branch is 190 square - miles, and the maximum and minimum discharges for the year ending September 30, 1924, were 5,570 and 26 second-feet. Analyses of four samples collected at Milltown (Nos. 46-49) are similar to the analyses for Far Hills but show a larger quantity of sulphate. This sulphate probably is brought in by Black River. Analyses 46 and 49 are shown graphically in Figure 16 to illustrate the variation in concentration with the discharge. 
Black River.-Black River is the main tributary to the North Branch. Above Pottersville it has a drainage area of 33 square miles, most of which is in the highlands. The drainage basin includes a marsh from which the color of the river water is derived. The maximum and minimum discharges at Pottersville for the year ending September 30, 1924, were 740 and 4 second-feet.

Analyses of samples collected at Pottersville (Nos. 50-52) show considerable variation in composition with the discharge. The unusually large proportion of sulphate in the water of Black River may come from iron mines along the river. The relatively high sulphate is evident from Figure 17, in which analysis 52 is plotted with others for the Raritan Basin.

Analyses 37 and 44, shown in Figure 17, for the South and North branches of Raritan River, represent bicarbonate waters with little sulphate; No. 52 shows more sulphate than bicarbonate; and No. 41 , which represents the river below the junction of the South Branch, the North Branch, and the Black, has an intermediate quantity of sulphate.

Millstone River.-Millstone River rises southeast of Hightstown and flows into the Raritan below Manville. The Millstone is 35 miles long and has a drainage area of about 300 square miles. The larger part of the basin is in the Piedmont province. At Blackwells Mills the drainage area is 258 square miles and the maximum and minimum discharges for the year ending September, 1924, were 6,200 and 62 second-feet. The basin is rather densely populated. Analyses of four samples collected at Blackwells Mills (Nos. 53-56) indicate that the water is generally soft and low in mineral content. Analysis 56 is shown graphically in Figure 17.

Stony Brook.-A single analysis of water from Stony Brook at Princeton (No. 57) shows it to have about the average composition of Millstone River, which this brook enters near Princeton.

Green Brook.-Green Brook rises in the First and Second Watchung Mountains and flows into Raritan River at Boundbrook. Green Brook has a drainage area of 49 square miles, and the maximum and minimum discharges for the period from June 12 to September 30, 1924, were 800 and 10 second-feet. Analyses of four samples collected at Boundbrook (Nos. 58-61) indicate that at high stages of the stream the water is only slightly hard, but at low stages the water is hard and moderately high in mineral content. Plainfield sewage empties into Green Brook, and its effect is shown in the great increase in chloride at low stages of the stream when the diluting water is decreased while the volume of sewage keeps about the same. Analysis 60 is shown graphically in Figure 17. 
Lawrence Brook.-Lawrence Brook rises near Monmouth Junction and flows into the Raritan just below New Brunswick. It has a drainage area of 45 square miles, part of which is in the Piedmont province and part in the Coastal Plain. The drainage area above Patricks Corner is 29 square miles, and the maximum and minimum discharges at this point for the year ending September 30, 1924, were over 600 second-feet and 0.4 second-foot. Water is pumped from this stream at Weston Mills, below Patricks Corner, for the city supply of New Brunswick. Analyses of four samples taken at Patricks Corner (Nos. 62-65) show that the water is soft and low in mineral content. It is probably the least mineralized river water of northern New Jersey. Analysis 65 is shown graphically in Figure 17.

Summary.-The diagrams for Raritan River Basin in Figure 17 show a wide range in composition of the waters of the basin. The water of Lawrence Brook (No. 65) is one of the least mineralized surface waters of the northern part of the State, and that of Bound Brook one of the most highly mineralized. In general, however, the waters of the Raritan Basin are about the same in composition as those of the Passaic Basin. Their comparative softness and low mineral content place them definitely among the better waters of the United States for industrial use.

\section{SWIMMING RIVER}

Swimming River is formed by the junction of Hop and Yellow Creeks and joins Navesink River below tidewater. The maximum and minimum discharges of Swimming River at Redbank for the year ending September 30, 1924, were 2,000 and 13 second-feet.

Analyses of three samples from Swimming River at Redbank (Nos. 66-68) show changes in concentration with discharge, but the water is always low in dissolved solids and fairly soft. The sample collected February 6, 1924 (No. 66), carried an unusually large quantity of suspended matter for a surface water in New Jersey. Water from Swimming River is used after filtration by the Tintern Manor Water Co. for a public supply.

\section{MULIICA RIVER BASIN}

Mullica River.-Mullica River, which rises near Atco and empties into Great Bay, north of Atlantic City, 32 miles from its source, has a. drainage area of 412 square miles, all in the Coastal Plain. The river is tidal and navigable for 20 miles. The main river and its tributaries flow through cedar swamps, and the water is colored by organic matter in the swamps. Above Pleasant Mills Mullica River has a drainage area of 126 square miles. 
Analyses of samples from Mullica River at Atsion and at Pleasant Mills (Nos. 69 and 70) show the water to be a typical soft, highly colored swamp water It is not likely that the water changes much in composition throughout the year.

Batsto River.-Batsto River rises near the headwaters of the South Branch of Rancocas Creek, a tributary to the Delaware, and flows into Mullica River below Batsto. Above the dam at Batsto it has a drainage area of 70 square miles. Analysis 71 shows the water of Batsto River at Batsto to have much the same composition as that of Mullica River at Pleasant Mills.

Wading River.-Wading River rises west of Woodmansie and after flowing 22 miles, largely through swamp land, empties into Mullica River. The river is navigable for 8 miles from its mouth. Its drainage area is 189 square miles. The population in the drainage area of Wading River is only 7 to the square mile; in the rest of the basin of the Mullica the density is 46 to the square mile. Analysis 72 shows the water of East Branch of Wading River near Jenkins to have the same composition as the other waters sampled in the Mullica River Basin.

\section{ABSECON CREEK}

Absecon Creek rises northwest of Absecon and flows into the Atlantic Ocean. Its drainage area above the bridge at Absecon is 18 square miles and above the lower mill pond at the head of tidewater 12 square miles. Water from this creek is used as a part of the city supply for Atlantic City.

Analyses of four samples collected at the storage ponds of the Atlantic City Water Co. (Nos. 73-76) indicate that the water is soft and low in mineral content. It is, however, often highly colored. The color is bleached somewhat after long storage, so that the greatest color is likely to be present just after rains have washed into the pond water that has been in contact with organic matter in swamps for a long time.

\section{GRAAT EGG RIVRiR}

Great Egg River rises west of Berlin and flows into the Atlantic Ocean. It is 38 miles long and above Mays Landing (at the head of tidewater) has a drainage area of 216 square miles. Above Folsom the drainage area is about 51 square miles. The area drained is all in the Coastal Plain, and some of it is swamp land.

An analysis of a sample from Great Egg River at Folsom (No. 7f) shows that the water is soft and of low mineral content but noticeably colored. 


\section{MAURICE RIVER}

Maurice River rises near Glasssboro and empties into Delaware Bay 33 miles from its source. Above Millville, at the head of tidewater, it has a drainage area of 218 square miles. The entire drainage area is in the Coastal Plain, and the river is a characteristic southern New Jersey stream. The analysis of a sample taken at Malaga (No. 78) shows that the water is soft, low in mineral content, and colored like the other river waters of the southern part of the State.

\section{SUMMARY FOR SOUTHERN NEW JERSEY}

The samples collected for this report from the southern part of the State are remarkably similar in composition. They are soft, colored, and generally clear, and they carry only small quantities of dissolved mineral matter. Because of the similarity of conditions in the other drainage basins it is to be expected that similar water will be found in practically all the streams of southern New Jersey above the influence of salt water from the ocean or bay.

\section{DELAWARE RIVER BASIN}

\section{DELAWARE RIVER}

Delaware River rises on the west side of the Catskill Mountains in New York at an altitude of about 1,900 feet; at the mouth of Neversink Creek, at the extreme north tip of New Jersey, its altitude is 411 feet. The Delaware is 360 miles long and flows into Delaware Bay; the river and bay form the western boundary of New Jersey. About 45 per cent of the State is drained by streams tributary to the river or to the bay.

Water from Delaware River is used for public supply at several places, of which Trenton is the largest in New Jersey. A number of cities also make use of the river to carry their sewage away. Large volumes of water are taken for industrial use by plants situated on the river. A commission is now working out plans for the equitable and economical use of the river in the States of New York, New Jersey, and Pennsylvania.

At Belvidere Delaware River has a drainage area of 4,540 square miles, and the maximum and minimum discharges for the year ending September 30,1924, were 102,000 and 1,010 second-feet. Analyses 79-82 probably cover almost the whole range in concentration of the river water at Belvidere. The water has a low mineral content and is generally fairly clear and soft. The hardness shown in analysis 80 is sufficient to be objectionable for many uses.

At Riegelsville Delaware River has a drainage area of 6,190 square miles, and the maximum and minimum discharges for the year end- 
ing September 30,1924 , were 122,000 and 1,360 second-feet. Analyses 83-86, show the composition of the river water at Riegelsville to be practically the same as at Belvidere.

At Lambertville daily samples of river water were collected from September 8, 1906, to September 12, 1907. These were united in sets of 10 to make composites which were analyzed in the laboratory of the Geological Survey at Washington. The analyses were published in Water-Supply Paper 236. Three analyses (Nos. 87-89) representing composite samples are given in the table and are shown graphically in Figure 16. The range in composition of the river water at Lambertville in 1906 and 1907 is about the same as is shown by the analyses of samples collected occasionally at other points from 1923 to 1925 .

Delaware River above Trenton has a drainage area of 6,800 square miles. The maximum discharge at Trenton for the period 1913-1922 was 160,000 second-feet, in March, 1913; the minimum for the same period was 1,240 second-feet, for several days in 1914. Analyses 90-92 show about the same composition for the water at Trenton as the analyses of samples from other points. Analysis 92 is shown graphically in Figure 17.

TRIBUTARIES OF DELAWARE RIVER

Flat Brook.-Flat Brook rises near High Point, in the Kittatinny Mountains, and after flowing for 21 miles through the Appalachian Valley empties into the Delaware below Flatbrookville. The stream becomes swollen very quickly in time of flood. The total drainage area is 66 square miles, of which 65 square miles is above Flatbrookville. The maximum and minimum discharges at Flatbrookville in the year ending September 30, 1924, were 4,400 and 4 second-feet. Analyses of samples taken at Flatbrookville (Nos. 93-96) show the water to be low in mineral content, though at low stages it is slightly hard. Analysis 96 is shown graphically in Figure 17.

Paulins Kill.-Paulins Kill rises in the Kittatinny Mountains east of the head of Flat Brook and flows 36 miles to the Delaware. Above Blairstown Paulins Kill has a drainage area of 128 square miles. The maximum and minimum discharges at Blairstown in the year ending September 30,1924, were 1,680 and 6 second-feet. Analyses of four samples collected at Blairstown (Nos. 97-100) indicate that at average stages the river water is slightly hard but low in mineral content. Analysis 100 is shown graphically in Figure 17. The slightly greater content of calcium and magnesium in Paulins Kill as compared with Flat Brook is accounted for by limestone in the lower drainage basin of Paulins Kill.

Pequest River.-Pequest River rises near Pinkeyville and flows about 32 miles in a general southwesterly direction to its junction 
with Delaware River at Belvidere. It has a drainage area of 158 square miles. The southern and eastern edges of its basin are on gneiss, but the major portion of the basin is on limestone. Above Pequest the drainage area is 108 square miles; at this point the maximum and minimum discharges for the year ending September 30, 1924, were 593 and 17 second-feet. Analyses of samples collected at Pequest (Nos. 101-103) indicate that the river water is hard and moderately high in mineral content. Analysis 103 is shown graphically in Figure 17. The effect of the limestone in the drainage basin is clearly shown by the larger quantities of calcium and magnesium as compared with the quantities found in the waters from Flat Brook and Paulins Kill.

Beaver Brook.-Beaver Brook rises east of Blairstown and flows into Pequest River near Belvidere. It has a drainage area of 36 square miles. Near Belvidere the maximum and minimum discharges for the year ending September 30, 1924, were 579 and 3.1 secondfeet. Analyses of samples collected near Belvidere (Nos. 104-106) indicate that the water of Beaver Brook is similar in composition to the water of the Pequest. (Compare analyses 106 and 103, fig. 17).

Musconetcong River.-Musconetcong River rises in the Sparta Mountains and flows 52 miles southwest to its junction with the Delaware. The Musconetcong has a long, narrow basin with an area of 156 square miles in the highlands. Above. Hackettstown the drainage area of the river is 70 square miles, and at this point the maximum and minimum discharges in the year ending September 30 , 1924, were 750 and 6 second-feet. Above Bloomsbury the drainage area is 143 square miles, and the maximum and minimum discharges for the year ending September 30, 1924, were 1,300 and 25 secondfeet. The population in the basin of the Musconetcong is about 80 to the square mile, and the principal industry is agriculture. Analyses of three samples collected at Hackettstown (Nos. 107-109) indicate that the water is soft and is low in mineral content. The analysis of one sample collected at Bloomsbury at a rather low stage of the river (No. 110) shows that at this stage the water is hard and somewhat more concentrated than the water at Hackettstown. This analysis is shown graphically in Figure 17. The quantity of calcium and magnesium bicarbonate is not so great as in the water of Pequest River and Beaver Brook but is greater than in waters from drainage basins with smaller proportions of their area underlain by limestone.

Assunpink Creek.-Assunpink Creek rises near Clarksburg, Monmouth County, and flows nearly due west into the Delaware at Trenton. The drainage area above Trenton is 89 square miles, of which 27 square miles is in the Piedmont province and the remainder in the 
Coastal Plain. The maximum and minimum discharges at Trenton during the year ending September 30, 1924, were 2,400 and 13 second-feet. Analyses of four samples collected at Trenton (Nos. 111114) indicate that the water is soft at high stages but is slightly hard and moderately high in mineral content at lower stages. The samples takken at the higher stages show considerable sediment. Sulphate is comparatively high in all the samples.

Rancocas Creek.-Rancocas Creek is the next to the largest tributary to the Delaware from New Jersey. Its drainage area is 301 square miles. The main stream is formed below Mount Holly by the union of the North Branch and the South Branch, both of which rise in the Coastal Plain. The North Branch of Rancocas Creek has a drainage area of 111 square miles above Pemberton. Some of the drainage area is swamp land, and the population in the basin is small. The maximum discharge at Pemberton for the year ending September 30, 1924, was not recorded but was over 900 second-feet; the minimum was 46 second-feet. The water supplies of Mount Holly and Pemberton are taken from the North Branch; the supply for Camp Dix is taken from Mount Misery Branch, which joins the North Branch at New Lisbon.

Analyses of three samples from the North Branch at Pemberton (Nos. 115-117) and of one sample from Mount Misery Branch at Camp Dix (No. 118) show the water of these streams to be soft, of low mineral content, and slightly colored. They are quite like the stream waters in the eastern part of southern New Jersey. Analysis 117 is shown graphically in Figure 17 for comparison with the analyses of the northern tributaries to Delaware River. The low bicarbonate of the samples from the North Branch and Mount Misery Branch suggests that at times the waters of these streams may be actually acid. Whether so or not, they are likely to corrode pipes. The South Branch of Rancocas Creek above Eayrestown has a drainage area of 62 square miles. Haynes Creek flows into the South Branch near Eayrestown. The population in the basins of these two streams is small. Vermeule ${ }^{5}$ estimated that Mount Misery Branch and the North Branch could supply 17,800,000 gallons a day, and that the South Branch above Vincenttown could supply 9,000,000 gallons a day in the driest years without storage.

Analyses of samples from the South Branch (No. 119) and from Haynes Creek (No. 120) collected near Eayrestown indicate that the water of these streams is soft and of low mineral content but is a little more concentrated than the water of the North Branch.

5 Vermeule, C. Ca, Report on water supply, water power, the flow of streams, and attendant phenomena: New Jersey State Geologist Final Rept., vol. 3, p. 254, 1894. 
Coopers Creek.-Coopers Creek rises in gravel hills and flows in a northwesterly direction to Camden, where it empties into the Delaware. The creek is tidal to the forks at Haddonfield. Above Haddonfield the branches flow through wooded areas having some outcrops of marl. The North Branch has a drainage area of 12 square miles. Vermeule ${ }^{6}$ estimated that with storage this branch would yield 5,660,000 gallons a day. Analysis 121 indicates that the water of Coopers Creek at Haddonfield is soft, low in mineral content, and similar in composition to that of other streams in southern New Jersey.

\section{SUMMARY}

The surface waters of New Jersey are one of the most valuable natural resources of the State. They are used for public water supplies of nearly all the larger cities, and they furnish the great quantities of water required for some of the leading industries. Where unpolluted, these waters are generally clear and contain only moderate quantities of dissolved mineral constituents. The waters in the southern part of the State are softer but more highly colored than the waters in the northern part.

\section{ANALYSES OF SURFACE WATERS}

The following table gives analyses of typical samples of surface waters of New Jersey. The usual constituents are reported in parts per million. In addition to the determined constituents of the dissolved mineral matter the table gives the calculated hardness, and for some samples, the quantity of suspended matter and the total iron. Nearly all the analyses were made by C. S. Howard; exceptions are indicated in footnotes.

The analyses are arranged in the order in which the drainage basins and streams are given in reports of stream measurements published by the United States Geological Survey. The following list of streams in alphabetic order shows the numbers of the analyses in the table for each stream.

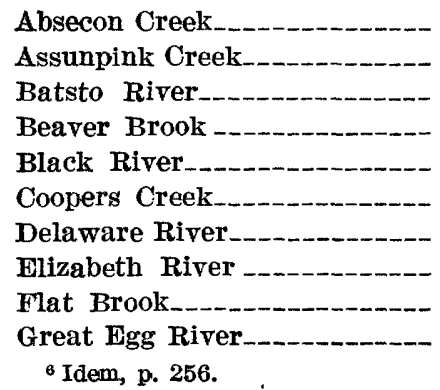

Absecon Creek

Assunpink Creek

Batsto River

Beaver Brook

Black River

Coopers Creek

Delaware River

73-76 111-114

71

104-106

50-52

121

79-92

25-27

93-96

77
Green Brook

Hackensack River

Haynes Creek

Lawrence Brook

Maurice River.

Millstone River

Mount Misery Branch

Mullica River

Musconetcong River

Passaic River
58-61

62-65

107-110 
Paulins Kill

Pequannock River

Pequest River

Rahway River

Ramapo River

Rancocas Creek:

North Branch

South Branch

Raritan River.

North Branch

South Branch
97-100 Robinsons Branch (of Rahway

21 River)

30

101-103 Rockaway River.___._. 9, 10

28,29 Saddle River._._._._._._._. 22-24

14-18 Stony Brook

Swimming River

115-117 Wading River-____._._._. 72

119 Wanaque River._________ 19,20

38-41 Whippany River__._._._._._. 11-13

$42-49$

31-37 


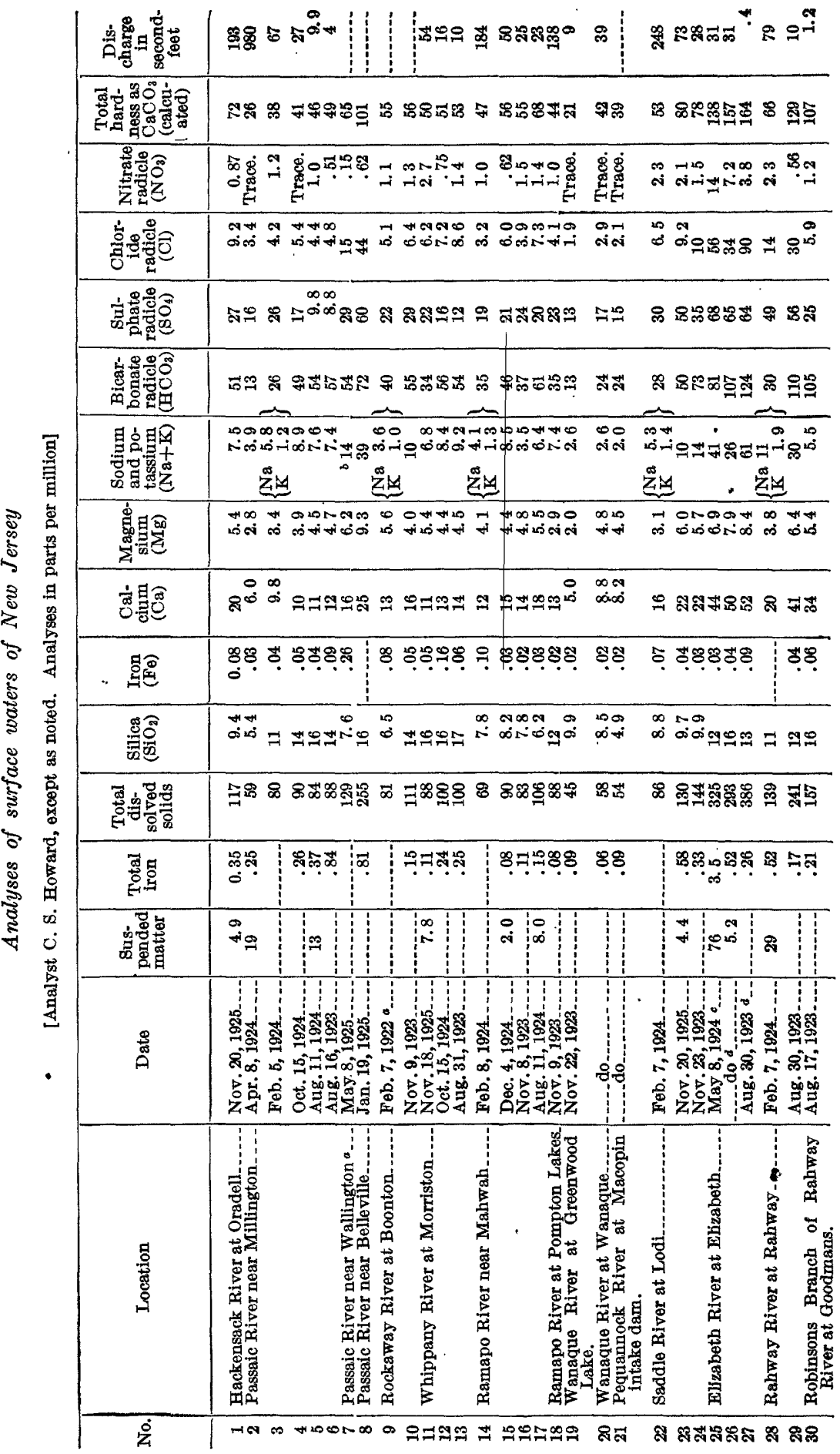




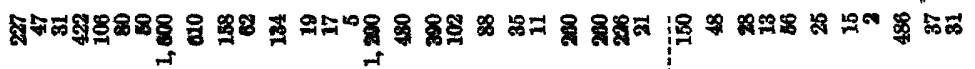

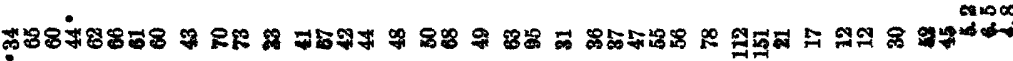

ใR8.

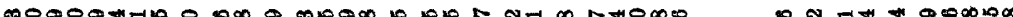

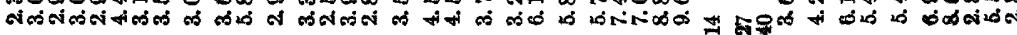

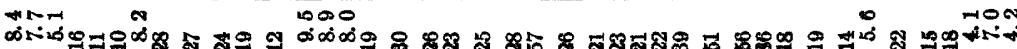

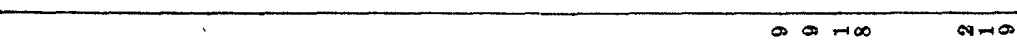

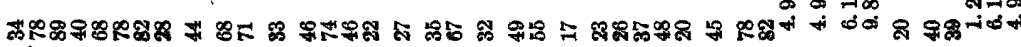

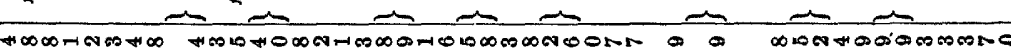

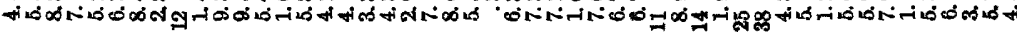

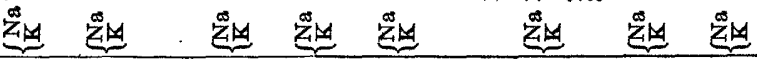

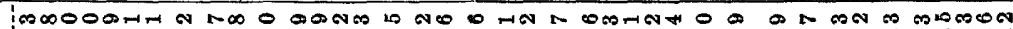

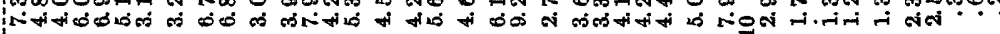

:

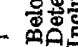

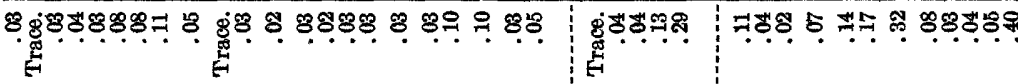

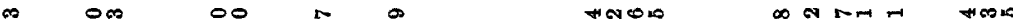
때붕

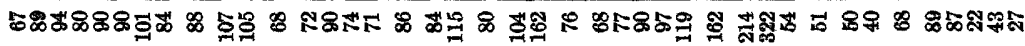

\begin{tabular}{|c|c|c|c|c|c|c|c|c|c|}
\hline 20.7 $8 \%$ & హ్ & \multirow[t]{2}{*}{ 9ึ? } & 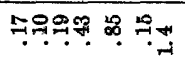 & \multicolumn{4}{|c|}{ 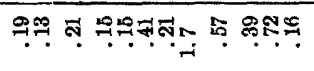 } & \multicolumn{2}{|c|}{ สำ n } \\
\hline $\begin{array}{l:ll}\infty & \infty \infty \\
\infty & 1 & 1\end{array}$ & : & & 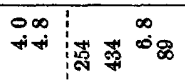 & $\Rightarrow$ & 윽 & \% & i & 居 & $\begin{array}{l}0000 \\
2000-1\end{array}$ \\
\hline
\end{tabular}

ริ่ 仙

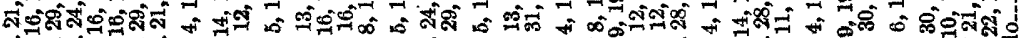

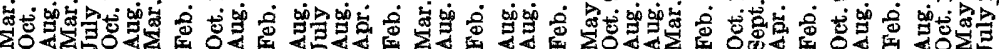

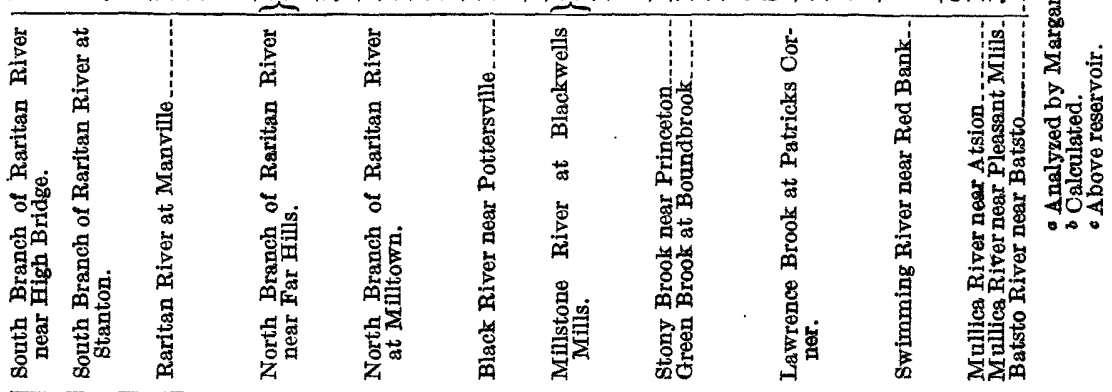

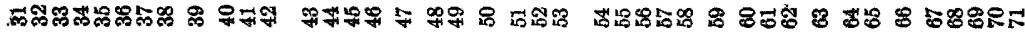


118 CONTRIBUTIONS TO HYDROLOGX OF UNITED STATES, 1927

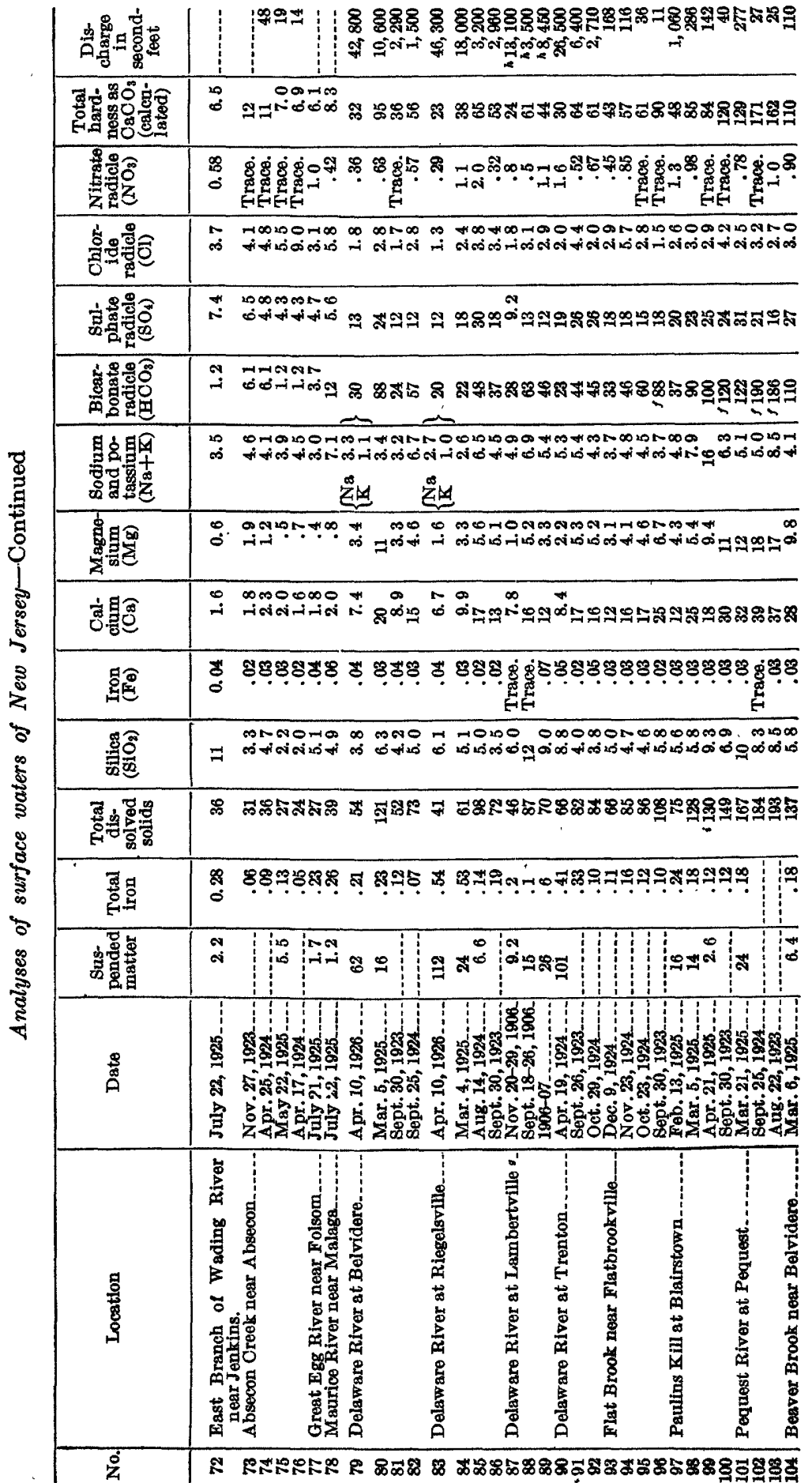




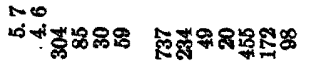

$\infty \quad-1$

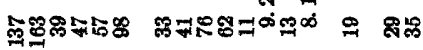

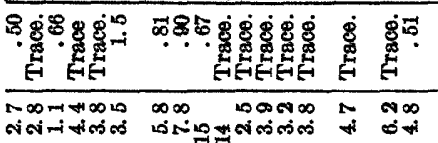

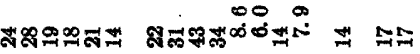

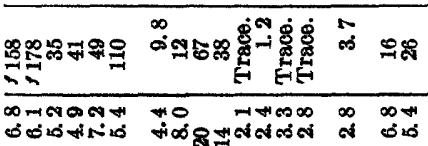

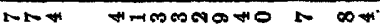

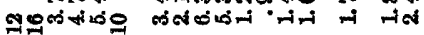

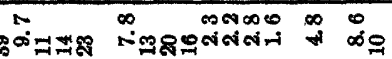

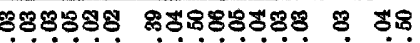

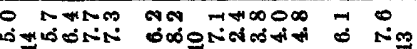

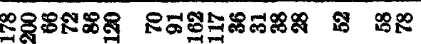

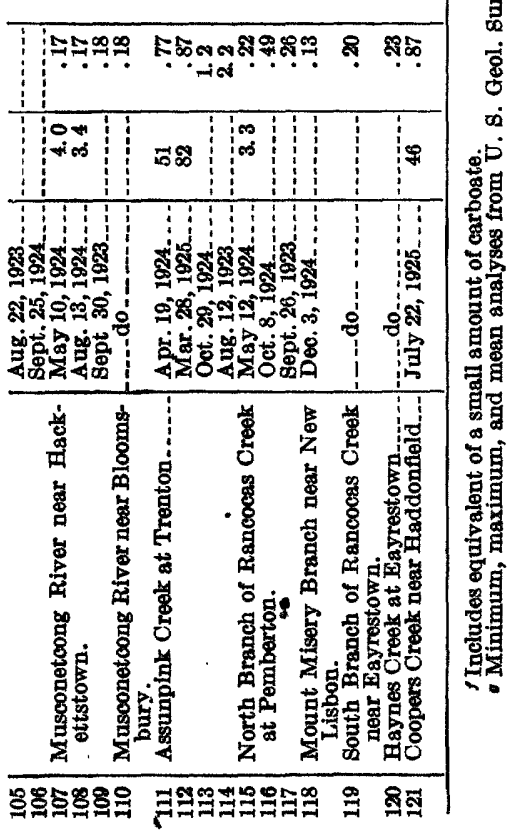

